\title{
Land based disposal of wastewater: fate of phosphorus
}

\author{
I. Vogeler ${ }^{1,2}$, R. Cichota ${ }^{2}$ \& F. Witing ${ }^{3}$ \\ ${ }^{1}$ HortResearch, Palmerston North, New Zealand \\ ${ }^{2}$ AgResearch, Palmerston North, New Zealand \\ ${ }^{3}$ Dresden University, Germany
}

\begin{abstract}
Worldwide, large quantities of wastewater are produced, including municipal effluent, dairy-shed effluent, and wastewater from factories. Most wastewater is treated to remove solids and contaminants. But even treated wastewater may still contain organic matter and high levels of nutrients, such as nitrogen and phosphorus (P). To assess the feasibility of effluent disposal to land with respect to $\mathrm{P}$ leaching to groundwater and build up at the soil surface leaching experiments were performed in the laboratory and in the field. The soil used for the study was the Kawhatau stony silt loam from New Zealand. In the laboratory undisturbed soil columns were leached under steady unsaturated flow conditions using either wastewater, or solutions containing 6 or $60 \mathrm{ppm}$ of phosphorus. In the field drainage lysimeters were irrigated with wastewater or a solution containing $60 \mathrm{ppm}$ at a rate of $30 \mathrm{~mm} /$ day.

Results from the leaching study in the laboratory show that after an infiltration equivalent to about 1 year of application, the $\mathrm{P}$ concentration in the in drainage water was below $0.4 \mathrm{ppm}$, regardless of the input concentration. Thus under the unsaturated, steady state flow conditions, the silt loam adsorbed all the applied P. In the field $\mathrm{P}$ concentrations in the drainage water after $2500 \mathrm{~mm}$ of wastewater application were below $0.3 \mathrm{ppm}$ in all lysimeters, except one, where preferential flow occurred and $\mathrm{P}$ concentrations reached $2 \mathrm{ppm}$.

A model, based on the convection dispersion equation, simply linked with the Freundlich adsorption isotherm could not be used successfully to describe the build up and movement of $\mathrm{P}$ in the soil.
\end{abstract}

Keywords: P leaching , CDE dispersion equation, Freundlich isotherm. 


\section{Introduction}

Onsite wastewater treatment systems, such as septic tanks, are common in urban areas, which are not serviced by centralised waste-water systems. These systems are designed for application of primary treated wastewater into the natural soil, which acts as an absorption system for solids and nutrients at relatively low cost [1]. After passing through the soil adsorption system, the wastewater is undergone a secondary treatment process. With increasing numbers and densities of septic tanks in urban areas there is a growing awareness and concern over system performance with respect to removal of bacteria and nutrients. Typical concentrations of organic and inorganic phosphorus from residential septic tanks range between 4-8 and 8-12 mg/l. Poor performance of onsite wastewater treatment has been reported, often due to inadequate soil assessment prior to the installation of the system [2]. While phosphorus is mainly lost via runoff and erosion, elevated levels of soil $\mathrm{P}$, and leaching of $\mathrm{P}$ from repeated waste application has been reported [3-7].

Modelling the fate and transport of nutrients and contaminants is an efficient and feasible means for assessing the sustainability of long term wastewater application, as well as for determining maximum loading rates. However an accurate, yet simple, description of the leaching and sorption processes in the soil is needed. Phosphorus adsorption by soils is often described by an instantaneous initial transfer from the soil solution to the sorbed phase followed by a slow transfer. Various time dependent sorption reactions, including instantaneous and kinetic reactions and diffusion precipitation, have been developed [8, 9]. Models, based on such adsorption reactions require the determination of various parameters, which are generally not known and require time consuming experiments. Large scale information on P sorption capacity of soils is often limited to $\mathrm{P}$ retention capacity or $\mathrm{P}$ adsorption isotherms determined from batch experiments in the laboratory with equilibrium times of 24 hrs.

Leaching experiments were carried out in the laboratory (i) to determine if the soil around Tararua Road, Levin, proposed for subdivision with on on-site wastewater systems, can accommodate the phosphate loading originating from the wastewater without ill effects on the groundwater and (ii) to verify if the convection dispersion equation (CDE) linked with a simple adsorption isotherm can describe the experimental data and be used to assess the long term sustainability of wastewater application from septic tanks to the soil.

\section{Methods and materials}

The soil used for the study was the Kawhatau stony silt loam, which is the dominant soil within the proposed subdivision on Tararua Road, Levin, New Zealand. The upper soil (0-500 mm depths) contains $15 \%$ sand, $60 \%$ silt and $25 \%$ clay, with $25 \%$ stones in the upper $200 \mathrm{~mm}$ and $35 \%$ in the depth from 200 to $500 \mathrm{~mm}$. The soil has a carbon content of $9.5 \%$, a total $\mathrm{N}$ content of $1.1 \%$, and a $\mathrm{pH}$ of 6.0 . 
The wastewater was obtained from the Palmerston North Wastewater Treatment Plant (Totara Road) in March 2008. Wastewater was taken from the first of the two aerated lagoons for secondary treatment, before undergoing $\mathrm{P}$ removal treatment. The wastewater had a $\mathrm{P}$ concentration of $6 \mathrm{mg} / \mathrm{l}$, which is in the range of $\mathrm{P}$ concentrations typically given for new and improved septic tanks.

\subsection{Batch $P$ adsorption isotherm}

Phosphorus adsorption in the soil was determined from batch experiments. Samples of the topsoil taken to a depth of $150 \mathrm{~mm}$ were air dried, sieved $(<2 \mathrm{~mm})$ and subsamples $(1 \mathrm{~g})$ were then shaken with $10 \mathrm{ml}$ of $0.01 \mathrm{M} \mathrm{CaCl}_{2}$ containing varying amounts of phosphate $\left(10\right.$ to $\left.200 \mathrm{mg} \mathrm{P} \mathrm{l}{ }^{-1}\right)$ added as $\mathrm{KH}_{2} \mathrm{PO}_{4}$ in an end-over-end shaker for $40 \mathrm{~h}$ at $25^{\circ} \mathrm{C}$. Phosphate concentration in the solutions was measured by the vanado-molybdate colorimetric method [10]. The amount of $\mathrm{P}$ adsorbed was calculated from the $\mathrm{P}$ added and not recovered in the solution. The adsorption isotherm was fitted to the Freundlich equation.

\subsection{Column leaching experiments}

For the leaching experiments in the laboratory undisturbed soil columns, 100 $\mathrm{mm}$ in diameter and $150 \mathrm{~mm}$ long were taken after removing the pasture. Leaching experiments were carried out in the laboratory under controlled, unsaturated flow conditions using a leaching apparatus, as described in Vogeler et al. [11]. The pressure potential at the top and bottom of the columns was kept at $-80 \mathrm{~mm}$, resulting in flow rates of about $2.5 \mathrm{~mm} \mathrm{~h}^{-1}$. Three different leaching experiments were carried out. All three columns were pre-equilibrated by leaching with about $1000 \mathrm{~mm}$ of $0.005 \mathrm{M} \mathrm{CaCl}_{2}$. Then Column A was leached with wastewater, Column $\mathrm{B}$ and $\mathrm{C}$ with solutions of $\mathrm{KH}_{2} \mathrm{PO}_{4}$. For Column $\mathrm{B}$ a concentration of 6 ppm $\mathrm{P}$ was chosen, which is about the $\mathrm{P}$ concentration in the wastewater. To investigate the influence of concentration on phosphate movement Column $\mathrm{C}$ was leached with $60 \mathrm{ppm} \mathrm{P.} \mathrm{A} \mathrm{nonreactive} \mathrm{tracer,}$ bromide, was also added to the solution used for column $\mathrm{C}$. The leachate was collected in aliquots ranging from 50 to $120 \mathrm{ml}$ and analysed for $\mathrm{P}$ as described below. After leaching with about $2000 \mathrm{~mm}$ the columns were sectioned into 30 mm thick layers. Sub-samples of each layer were taken for the determination of the gravimetric water content, the total $\mathrm{P}$ concentration, Olsen $\mathrm{P}$, water-soluble $\mathrm{P}$ (WS-P), and calcium-chloride extractable $\mathrm{P}\left(\mathrm{CaCl}_{2}-\mathrm{P}\right)$. Olsen $\mathrm{P}$ was determined as described in Blakemore et al. [10], and total $\mathrm{P}$ was determined from the increase in $0.5 \mathrm{M} \mathrm{H}_{2} \mathrm{SO}_{4}$-soluble phosphorus caused by ignition of the soil based on the procedure of Blakemore et al. [10] and determination of the total phosphate by flow injection analysis. For the determination of WS-P and $\mathrm{CaCl}_{2}$ $\mathrm{P}$ one gram of dry soil was shaken for 1 hour with $10 \mathrm{ml}$ of deionized water or $0.005 \mathrm{M} \mathrm{CaCl}_{2}$, and then filtered. The extracts and leachates were analysed for by the method of Murphy and Riley [12] by using a Microplate Reader Fluostar Optima.

\subsection{Drainage lysimeters}

For the drainage lysimeters six undisturbed soil columns, $150 \mathrm{~mm}$ in diameter and $300 \mathrm{~mm}$ long were taken in the field in February 2008. The soil columns 
were placed into a drainage lysimeters, similar to the fluxmeters described by Gee et al. [13]. The drainage lysimeters consisted of a soil core placed ontop of a funnel, which is inserted into a $1 \mathrm{~m}$ long tube, from which a rope created a hanging water columns of $500 \mathrm{~mm}$. The rope, $15 \mathrm{~mm}$ in diameter, was made of fibreglass wick material, that was kiln dried at $400^{\circ} \mathrm{C}$ for $3 \mathrm{hrs}$ to remove glue and organic materials. The funnel was filled with a $30 \mathrm{~mm}$ layer of acid washed sand and then the soil column was placed on top. Ryegrass (Lolium perenne $\mathrm{cv}$ Grassland Nui) was sewn on 6th of March (Day of Experiment, DOE = 1). Irrigation started 5 days later, with three of the drainage lysimeters receiving wastewater and the other three a solution containing $60 \mathrm{ppm} \mathrm{P.} \mathrm{To} \mathrm{ensure}$ optimal nitrogen status of the soil, the lysimeters irrigated with $\mathrm{P}$ solution were fertilised on DOE 41 and 95 with $4 \mathrm{~g}$ Calcium Ammonium Nitrate (CAN 17, which contains $8.8 \%$ calcium and $17 \%$ nitrogen). The lysimeters were irrigated at a rate of $15-30 \mathrm{~mm} /$ day depending on the moisture status of the soil. The drainage was sampled via a suction pump every 3 to 7 days, and the pasture was cut back to a height of $20 \mathrm{~mm}$ every 7 to 14 days, depending on the growth rate.

\section{Modelling}

To describe the transport of $\mathrm{P}$ through the soil we used the classical convection dispersion model (CDE). For one-dimensional transport under steady state the $\mathrm{CDE}$ for reactive solutes can be written as [14]:

$$
\theta \frac{\partial C_{s}}{\partial Q}+\rho \frac{\partial S_{s}}{\partial Q}=\lambda \frac{\partial^{2} C_{s}}{\partial z^{2}}-\frac{\partial C_{s}}{\partial z}
$$

where $\theta$ is the volumetric water content $\left(\mathrm{m}^{3} \mathrm{~m}^{-3}\right), C$ is the soil solution concentration of ion species s $\left(\mathrm{mol} \mathrm{m}^{-3}\right), Q$ the cumulative infiltration depth $(\mathrm{m})$, $\rho$ the bulk density $\left(\mathrm{kg} \mathrm{m}^{-3}\right), S$ is the concentration of the ion s on the solid phase of the soil $\left(\mathrm{mol} \mathrm{kg}^{-1}\right), \lambda$ the dispersivity $(\mathrm{m})$, and $z$ the depth (m)

A commonly used adsorption isotherm is the Freundlich equation, which has been found to describe well the adsorption of anions, such as phosphorus, in soils [15], and is given by:

$$
S_{s}=k_{\mathrm{F}} C_{s}^{\mathrm{N}}
$$

where $\mathrm{k}_{\mathrm{F}}$, the distribution coefficient, and $\mathrm{N}$ are empirical coefficients.

\section{Results and discussion}

\subsection{Phosphorus adsorption isotherm}

The phosphorus adsorption isotherm (Figure 1) reflects the high $\mathrm{P}$ retention of the Kawhatau silt loam. The Freundlich equation was fitted to the data, resulting in a $K_{\mathrm{F}}$ value of $60 \mathrm{~L} \mathrm{~kg}^{-1}$ and a value for $N$ of 0.34 . 


\subsection{Leaching experiments}

The $\mathrm{P}$ concentrations (dissolved reactive phosphor) in the leachate during preleaching with $\mathrm{CaCl}_{2}$ ranged from 0.2 to $0.3 \mathrm{mg} \mathrm{l}^{-1}$. In Column A, leached with wastewater, the concentration remained low over the entire duration of the experiment, with a total application of about $800 \mathrm{~mm}$ (Figure 2). In Column B, leached with a $6 \mathrm{ppm} \mathrm{P}$ solution, and Column $\mathrm{C}$, leached with a $60 \mathrm{ppm} \mathrm{P}$ solution, the concentrations in the leachate increased slightly to about $0.4 \mathrm{mg} \mathrm{l}^{-1}$ after about $600 \mathrm{~mm}$. However even after about $1000 \mathrm{~mm}$ of infiltration, equivalent to about 14 pore volumes of wastewater application over one year at a rate of $3 \mathrm{~mm}$ day $^{-1}$, the $\mathrm{P}$ concentration in the leachates was low under all columns. This shows that under the controlled, unsaturated, steady state flow conditions, no preferential flow of $\mathrm{P}$ occurred.

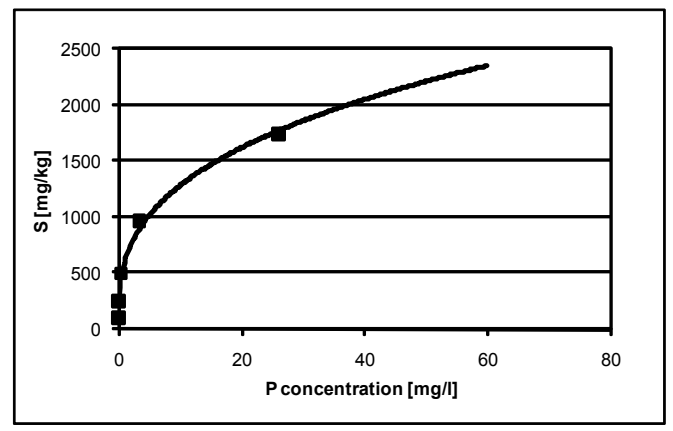

Figure 1: Phosphate adsorption isotherm for Kawhatau stony silt loam and fitted Freundlich isotherm with values for $K_{\mathrm{F}}$ of $60 \mathrm{~L} \mathrm{~kg}^{-1}$ and $N$ of 0.34 .

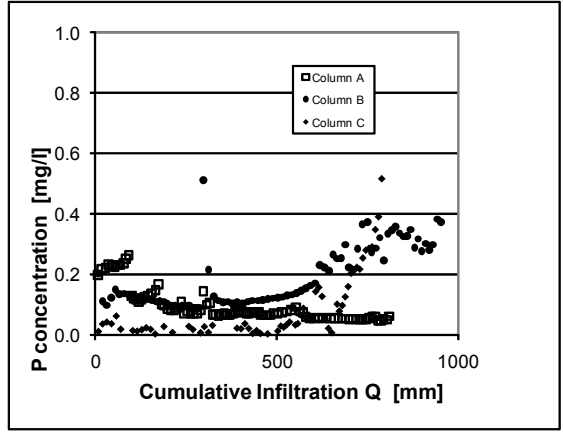

Figure 2: $\quad$ P concentrations in leachates from column $\mathrm{A}(\square), \mathrm{B}(\bullet)$ and $\mathrm{C}(\bullet)$.

The values for the resident $\mathrm{P}$ concentrations determined by the various extracts are presented in Table 1 for the three different columns and depths. 
Also given are the initial concentrations, as measured on subsamples taken adjacent to the columns. In the top $30 \mathrm{~mm}$ The WS-P and $\mathrm{CaCl}_{2}-\mathrm{P}$ concentrations, which represent the more readily de-sorbable forms of $\mathrm{P}$, are elevated in all three columns, compared with the initial concentration measured. Concentrations measured by water are in general higher than those measured by $\mathrm{CaCl}_{2}$.

Maguire and Sims [16] compared various soil $\mathrm{P}$ tests as an indicator for phosphorus leaching using a series of five different soils. They also found that $\mathrm{CaCl}_{2}-\mathrm{P}$ concentrations were lower than $\mathrm{W}-\mathrm{SP}$, and defined change points of $\mathrm{P}$, above which rapid increases in the leaching of dissolved reactive phosphorus occurred, as 8.6 for WSP and $1.59 \mathrm{mg} \mathrm{kg}^{-1}$ for $\mathrm{CaCl}_{2}-\mathrm{P}$. According to their study $\mathrm{P}$ concentrations in topsoils should be kept below these values to avoid leaching. In our experiments $\mathrm{W}-\mathrm{SP}$ and $\mathrm{CaCl}_{2}-\mathrm{P}$ concentrations are higher than their respective change points for Column $\mathrm{C}$ up to a depth of $75 \mathrm{~mm}$ following leaching with about $800 \mathrm{~mm}$ of a solution containing $60 \mathrm{ppm} \mathrm{P}$. Values of $\mathrm{CaCl}_{2}-\mathrm{P}$ are also slightly higher than the change point in column A following about $800 \mathrm{~mm}$ of irrigation with wastewater. This suggests that $\mathrm{P}$ leaching from the soil is likely to increase with continued wastewater application.

Table 1: Phosphorus concentration resident in the soil initially and at the end of the leaching experiments as determined by water (WS-P), $0.01 \mathrm{M} \mathrm{CaCl}_{2}$, Olsen solution and total P.

\begin{tabular}{|c|c|c|c|c|c|}
\hline \multirow{2}{*}{ Column } & \multirow{2}{*}{$\begin{array}{l}\text { Depth } \\
{[\mathrm{mm}]}\end{array}$} & \multicolumn{4}{|c|}{ Method for $\mathrm{P}$ concentration $\left[\mathrm{mg} \mathrm{kg}^{-1}\right]$} \\
\hline & & WS-P & $\mathrm{CaCl}_{2}-\mathrm{P}$ & Olsen-P & Total P \\
\hline \multirow{5}{*}{ initial } & 15 & 1.9 & 1.1 & 54.3 & 2145.7 \\
\hline & 45 & 1.8 & 1.5 & 37.6 & 2060.7 \\
\hline & 75 & 0.8 & 1.6 & 34.5 & 2000.0 \\
\hline & 105 & 1.5 & 1.2 & 35.0 & 1854.0 \\
\hline & 135 & 0.9 & 1.4 & 30.6 & 1486.9 \\
\hline \multirow{5}{*}{ A } & 15 & 2.4 & 2.6 & 65.7 & 2265.5 \\
\hline & 45 & 1.6 & 2.1 & 52 & 2144.4 \\
\hline & 75 & 1.1 & 1.8 & 43.1 & 2012.7 \\
\hline & 105 & 1.0 & 2.1 & 46.0 & 1878.3 \\
\hline & 135 & 0.5 & 1.7 & 30.1 & 1322.1 \\
\hline \multirow{5}{*}{ B } & 15 & 3.4 & 1.5 & 59.7 & 2422.9 \\
\hline & 45 & 2.2 & 1.1 & 55.9 & 2111.7 \\
\hline & 75 & 1.8 & 0.9 & 41.6 & 1809.3 \\
\hline & 105 & 1.3 & 1.1 & 42.3 & 1412.9 \\
\hline & 135 & 1.3 & 1.0 & 55.7 & 1102.2 \\
\hline \multirow{5}{*}{$\mathrm{C}$} & 15 & 64.7 & 24.5 & 177.2 & 3022.2 \\
\hline & 45 & 21.6 & 7.0 & 153.5 & 2632.9 \\
\hline & 75 & 13.9 & 4.2 & 119.6 & 2395.7 \\
\hline & 105 & 4.1 & 1.7 & 88.5 & 1854.0 \\
\hline & 135 & 1.5 & 1.3 & 55.3 & 1486.9 \\
\hline
\end{tabular}


The Olsen $\mathrm{P}$ concentrations in the soil at the end of the experiment have slightly increased in Columns A and B compared with the initial concentrations, but within the range typically found in New Zealand [17]. Olsen P concentrations have highly increased in Column $\mathrm{C}$, the column leached with the higher $\mathrm{P}$ concentration of $60 \mathrm{mg} \mathrm{l}^{-1}$. Over the three columns $15-25 \%$ of the wastewater applied $\mathrm{P}$ was recovered as Olsen $\mathrm{P}$, the remaining part is likely to be transferred into the P-pool unavailable for plants. Such high Olsen P values in the topsoil also have the potential to increase $\mathrm{P}$ loss via runoff, with the well known detrimental impacts on freshwater quality. McDowell and Condron [18] used an empirical equation to estimate the dissolved reactive phosphorus (DPR) from the Olsen $\mathrm{P}$ values and the phosphate retention capacity (PR) of the soil: $\mathrm{DPR}=0.024$ (Olsen $\mathrm{P} / \mathrm{PR})+0.024$. According to their approach estimated DPR values in our study were $0.038,0.04,0.038$, and $0.068 \mathrm{mg} \mathrm{l}^{-1}$ for the initial soil, Column A,B, and C. These values are all much higher than the concentration of $0.01 \mathrm{mg} \mathrm{P}^{-1}$, the threshold value given for stimulating algae growth.

The total $\mathrm{P}$ concentration in the soil was elevated at the end of the experiment, compared with the initial concentration, in the top 15 to $45 \mathrm{~mm}$ in columns A and B and to a depth of $75 \mathrm{~mm}$ in column C. The recovery of the applied $\mathrm{P}$ as calculated from the changes in total soil $\mathrm{P}$ and leachate concentrations ranged from 88 to $127 \%$.
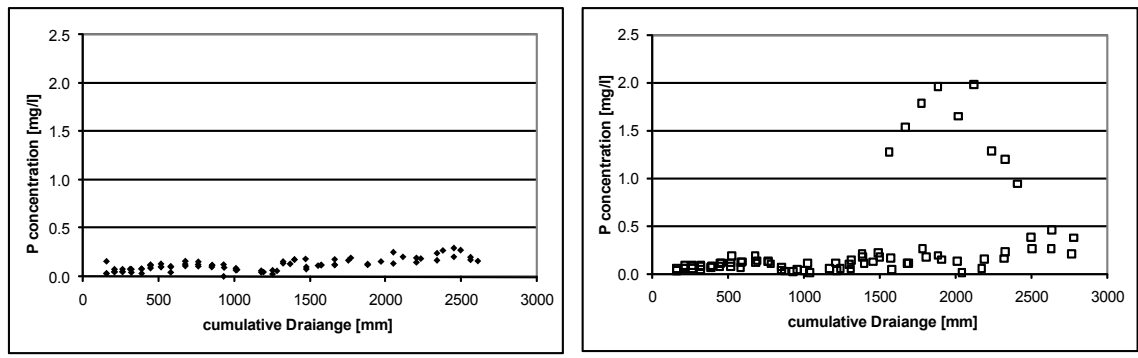

Figure 3: $\quad \mathrm{P}$ concentrations in leachates from the drainage lysimeters irrigated with (a) a solution containing $60 \mathrm{ppm} \mathrm{P}$, and (b) wastewater. Three replicate lysimeters are shown.

\subsection{Drainage lysimeters}

Results from the drainage lysimeters in the field also suggest little $\mathrm{P}$ leaching (Figure 3). Even after an application of $2500 \mathrm{~mm}$ of wastewater or P solution the $\mathrm{P}$ concentration in the drainage did not change much compared to the with $\mathrm{P}$ concentrations below $0.2 \mathrm{mg} \mathrm{l}^{-1}$. These concentrations are higher than the threshold value given for stimulated algae growth of $0.01 \mathrm{mg} \mathrm{l}^{-1}$, but were measured at a depth of $300 \mathrm{~mm}$ and are likely to be decrease before entering the groundwater. This application amount equates to $2.5 \mathrm{yrs}$ based on a daily application of $3 \mathrm{~mm} /$ day. With continued application of excessive amounts of $\mathrm{P}$, as will be with wastewater, the soil may eventually become saturated with $\mathrm{P}$, 
enabling increased leaching of $\mathrm{P}$. In one of the drainage lysimeters irrigated with wastewater preferential flow of $\mathrm{P}$ occurred, resulting in drainage concentrations of up to $2 \mathrm{mg} \mathrm{l}^{-1} \mathrm{P}$.

\section{$5 \quad$ Modelling}

The $\mathrm{P}$ status in the topsoil is a valuable early indicator for the risk of $\mathrm{P}$ leaching. However for long term risk assessment deterministic models are needed. We used the convection dispersion equation (CDE), linked with the nonlinear Freundlich equation and the adsorption parameters determined from the batch experiments to simulate the $\mathrm{P}$ concentration in the leachate and the final soil resident concentration. Only results from the lysimeters studies, column $\mathrm{C}$, are presented, as this column showed the largest differences between initial and final $\mathrm{P}$ concentrations. A value of $10 \mathrm{~mm}$ for $\lambda$, the dispersivity, in equation 1 was obtained from the breakthrough curve of bromide (data not shown). As a first modelling attempt only two P-pools were considered, namely the soil solution and the total $\mathrm{P}$ in the soil. This $\mathrm{P}$ pool was assumed to be in equilibrium with the soil solution concentration, according to the adsorption isotherm (Figure 1). According to the model $42 \%$ of the applied $\mathrm{P}$ would have leached over the entire duration of the experiment (Figure 4a), and the soil resident concentration at the end of the experiment would be much lower than measured (Figure $4 b$ ).
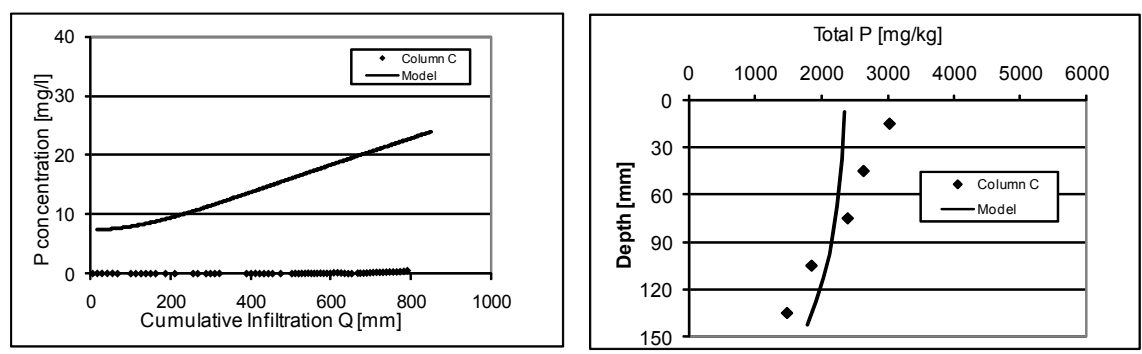

Figure 4: $\quad$ Measured and modelled total $\mathrm{P}$ concentration of Column $\mathrm{C}$ using the $\mathrm{CDE}$ with the Freundlich equation with $\mathrm{k}_{\mathrm{F}}$ of $60 \mathrm{~L} \mathrm{~kg}^{-1}$ and $\mathrm{n}$ of 0.34 and assuming equilibrium between soil solution concentration and total soil $\mathrm{P}$ in a) leachate and b) resident in the soil at the end of the experiment.

This disagreement between model and data suggests that a more complex configuration for the model is needed. A large fraction of the applied P should have been transferred into a more stabile $\mathrm{P}$ pool, which is not in equilibrium with the soil solution concentration. Thus as a next step three different P-pools were considered, the soil solution, a labile pool that is in equilibrium with the soil solution concentration, and a stable $\mathrm{P}$ pool. The labile pool was taken as being the Olsen $\mathrm{P}$, and the stabile pool taken as the difference between measured Olsen $\mathrm{P}$ and total $\mathrm{P}$ concentration initially in the soil. The $\mathrm{P}$ applied to the soil surface 
was assumed to equilibrate with the labile, or Olsen-P pool, according to the Freundlich equation. Model results show no $\mathrm{P}$ leaching, but a much higher Olsen P-concentration in the top soil than measured, and thus also a higher total $\mathrm{P}$ concentration in the top $300 \mathrm{~mm}$ of the soil column (Figure 5). This suggests that a fraction of the applied $\mathrm{P}$ is transferred into the stabile P-pool. This transfer, however, seems to be time dependent, as the $\mathrm{P}$ concentration is not only higher in the top, but up to a depth of $75 \mathrm{~mm}$. Godlinski et al. [19] could simulate data from a long term lysimeter study reasonable well assuming simply, that $10 \%$ of the average adsorbed $\mathrm{P}$ is annually transferred into a fixed $\mathrm{P}$ pool. Various models have been developed that include different $\mathrm{P}$ pools and rate coefficients $[9,20]$, but soil information on $\mathrm{P}$ retention by various pools and their transfer rates are generally not available [21]. Similarly these data are not available for the soil used here, and cannot be determined from modelling, as this would require more data. Our modelling approach shows that the soil can accommodate more $\mathrm{P}$ than predicted simply based on a single $\mathrm{P}$ pool that is in equilibrium with the soil solution and can be described by a nonlinear Freundlich equation.

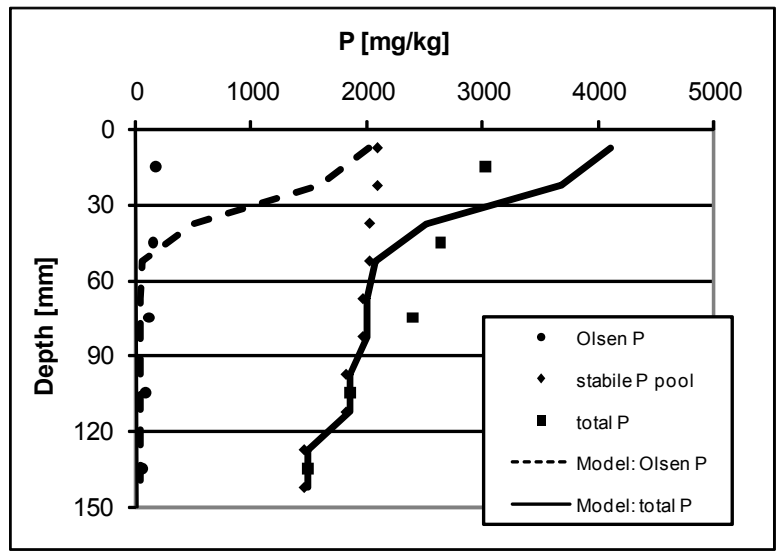

Figure 5: $\quad$ Measured and modelled $\mathrm{P}$ concentration of Column $\mathrm{C}$ using the $\mathrm{CDE}$ with the Freundlich equation with $\mathrm{k}_{\mathrm{F}}$ of $60 \mathrm{~L} \mathrm{~kg}^{-1}$ and $\mathrm{n}$ of 0.34 and assuming equilibrium between soil solution concentration and Olsen P.

\section{Conclusions}

The results of the column leaching experiment in the laboratory indicate that the Kawhatau stony silt loam with a high $\mathrm{P}$ retention had the capacity to retain most of the phosphorus originating from the wastewater application. Even after a total application of $800 \mathrm{~mm}$, equivalent to wastewater application over one year at a rate of $3 \mathrm{~mm} \mathrm{day}^{-1}$, the $\mathrm{P}$ concentration in the leachates were below $0.4 \mathrm{mg} \mathrm{l}^{-1}$, irrespective of the $\mathrm{P}$ concentration of the leaching solution. However Olsen $\mathrm{P}$ concentrations in the topsoil were elevated, indicating a high risk of freshwater 
contamination by $\mathrm{P}$ in the case of surface runoff. Results from the drainage lysimeters in the field confirmed that the soil could accommodate the P loading from wastewater application over 2.5 years at a rate of $3 \mathrm{~mm} /$ day. In one of the lysimeters, however, preferential flow of $\mathrm{P}$ occurred, resulting in drainage concentrations of up to $2 \mathrm{mg} \mathrm{l}^{-1}$.

The convection dispersion equation, coupled with the non-linear Freundlich isotherm to describe $\mathrm{P}$ retention by the soil, could not accurately predict the movement and retention of $\mathrm{P}$ in the soil. The model needs to be improved to consider a second stable $\mathrm{P}$ pool with a time dependent transfer rate. Parameterisation of such a model was not be feasible with the limited data available from this study.

The study was limited to the feasibility of wastewater application with respect to phosphorus. Other contaminants, such as pathogens which can cause diseases in humans and livestock also need to be considered in future studies.

\section{Acknowledgement}

Fund for this research was provided by the Foundation for Research, Science and Technology under Contract C04X0301.

\section{References}

[1] Siegrist, R.L., Perspectives on the Science and Engineering of Onsite Wastewater Systems. Small Flows Journal, 2001. 2(4): p. 8-13.

[2] Carroll, S., Goonetilleke, A., Thomas, E, Hargreaves, M, Frost, R, Dawes, L. Integrated risk framework for onsite wastewater treatment systems, Integrated risk framework for onsite wastewater treatment systems. Environmental Management, 2006, 38(2): p. 286-303

[3] Harman, J., Robertson, W.D., Cherry, J.A., Zanini, L., Impacts on a Sand Aquifer from an Old Septic System: Nitrate and Phosphate. Ground Water, 1996. 34(6): p. 1105-1114.

[4] Elliot, H.A., G.A. O'Connor, P. Lu, and S. Brinton., Influence of water treatment residuals on phosphorus solubility and leaching. Journal of Environmental Quality, 2002. 31: p. 1362-1369.

[5] Nelson, N.O., Parsons, J.E. \& Mikkelsen, R.L., Field-scale evaluation of phosphorus leaching in acid sandy soils receiving swine waste. Journal of Environmental Quality, 2005. 34(6): p. 2024-2035

[6] Zvomuya, F., C.J. Rosen \& S.C. Gupta, Nitrogen and phosphorus leaching from growing season versus year-round application of wastewater on seasonally frozen lands. Journal of Environmental Quality, 2006. 35(1): p. 324-333

[7] Zvomuya, F., S.C. Gupta \& C.J. Rosen. Phosphorus leaching in sandy outwash soils following potato-processing wastewater application. Journal of Environmental Quality, 2005. 34(4): p. 1277-1285. 
[8] Van Der Zee, S., Leus, F. \& Louer, M. Prediction of phosphate transport in small columns with an approximate sorption kinetics model. Water Resources Research 1989. 25(6): p. 1353-1365.

[9] Chen, J.S., Mansell, S., Nkedi-Kizza, P. \& Burgoa, B.A. Phosphorus transport during transient, unsaturated water flow in an acid sandy soil. Soil Science Society American Journal, 1996. 60: p. 42-48.

[10] Blakemore, L.C.S., P.L.; Daly, B.K, Methods for Chemical Analysis of Soils. . New Zealand Soil Bureau Scientific Report 1987. 80: p. 103p.

[11] Vogeler, I., Scotter, D. R., Clothier, B. E., and Tillman, R. W., Anion transport through intact soil columns during intermittent unsaturated flow. Soil and Tillage Research, 1998. 45: p. 147-160.

[12] Murphy, J., and Riley, J.P., 1962. A modified single solution method for determination of phosphate in natural waters. Analytica Chimica Acta, 1962. 27: p. 31-36.

[13] Gee, G.W., Zhang, Z.F., \& Ward, A.L., 2003. A modified vadose zone fluxmeter with solution collection capability. Vadose Zone Journal, 2003. 2: p. 627-632.

[14] Vogeler, I., Scotter, D. R., Clothier, B. E. \& Tillman, R. W. Cation transport during unsaturated flow through two intact soils. European Journal of Soil Science, 1997. 48: p. 401-410.

[15] Mead, J.A., A comparison of the Langmuir, Freundlich and Tempkin equation to describe phosphate sorption by ferric oxide gel. Geoderma, 1981. 18: p. 295-307.

[16] Maguire, R. \& Sims, J.T. , Soil Testing to predict phosphorus leaching. Journal of Environmental Quality, 2002. 31: p. 1601-1609.

[17] Aye T. M., N.M.L., Bolan N. S., \& Hedley M. J. Phosphorus in soils of riparian and non-riparian wetland and buffer strips in the Waikato area, New Zealand. New Zealand Journal of Agricultural Research, 2006. 49: p. 349-358.

[18] McDowell, R. \& Condron, L.M., Estimating phosphorus loss from New Zealand grassland soils. New Zealand Journal of Agricultural Research, 2004. 47: p. 137-145.

[19] Godlinski, F., Reiche, E.W., Lennartz, B. \& Meissner, R., Simulation of phosphorus losses from lysimeters. Journal of Plant Nutrition and Soil Science, 2008. 171: p. 621-633.

[20] Aylmore, L.A.G. \& Murali, V, A convective-dispersive-adsorptive flow model for solute transport in soils. II. Evaluation of single and twocomponent adsorption models for phosphate movement in soils. Australian Journal of Soil Research, 1981. 19: p. 287-298.

[21] Radcliffe, D.E. \& Canbera, M.L. (eds.). Modeling of Phosphorus in the Environment. CRC Press, Boca Raton, Florida, 2007: p. 432 p. 